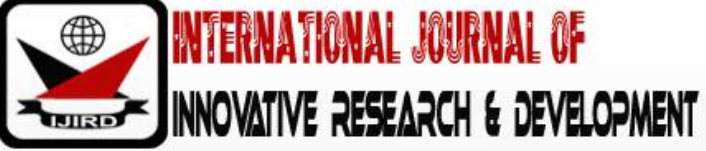

ISSN 2278 - 0211 (Online)

\section{Evaluation of Farmers' Perception on Extension Service Delivery in Jos South, Plateau State Nigeria}

\author{
Bassey Emmanuel Akpan \\ Principal Instructor, Montane Forest Research Station Jos. Plateau State, Nigeria \\ Dr. K.I Okeke- Agulu \\ Head of Station, Montane Forest Research Station Jos, Plateau State, Nigeria
}

\begin{abstract}
:
The study examined farmer's perception of agricultural extension services in Jos South Local Government Area of Plateau state, Nigeria. Data for this study was obtained mainly from primary source of information by the used of well-structured questionnaire and oral interviews, a total number of 109 farmers from four (4) communities in the study area were selected. Data was analyzed using descriptive statistics and three (3) and five (5) point's likert scale point's likert scale. Objective (i) and (ii) was analyzed using three (3) and five (5) point Likert scale. The result revealed that (4.75\%) of the farmers perceived that organization of field meeting with farmers are the best form off extension service delivery. Which means that most of the farmers has contact with extension agents. The result also revealed that to a very large extent, lack of transport facilities and lack of motivation are the most factors affecting extension services in the study area with $80.2 \%$ respectively.
\end{abstract}

Keywords: Assessment, farmers' perception

\section{Introduction}

Extension service delivery according to Oguremi and Olatunji (2013) is the process by which extension providers bring extension service from research institutes to farmers. Farmers perceive the extension service delivering in different ways. An alternative means of evaluating extension programs is measurement of the learning situation provided, which is extension delivery mechanism or process as means of measuring extension effectiveness (Ajayi, 2009). The agriculture extension service operates from the backdrop belief that increased agricultural productivity depends primarily upon the acceptance of improved cultural and technological changes at the rural farm level and that pleasant farmers can achieve higher farm yield only if they adopt recommended scientific farming techniques in place of their tradition practice.

Perception is the organizing and interpreting various stimuli into psychological experience. People tend to see the world around them in their own unique way and respond behaviorally according to their interpretation (Adereti and Ayayi, 2011). Ayansina (2011) posited that in everyday experience one tends to respond to stimuli that are relevant to ones need, interests and values. It is therefore, pertinent to understand farmer's perception of the extension service for better designing of programs to ensure smooth adaption and sustainable productivity.

\subsection{Statement of the Problem}

There is growing concern for provision of effective and sustainable agricultural extension service to majority of resource poor farmers in whose hands the bulk of agricultural production is left. Resource poor farmers belong to a complex diverse and risk prone agriculture, which supports several million of people in Africa (River et al; 2012). Extension delivery services is contingent upon many factors such as personal, social- economic, social-cultural and socialpolitical parameters (Babasanya, el al; 2013). They stressed further that availability of credits, compatibility of exiting technology with improved ones, suitability to farmer circumstances and needs, and the financial benefits influence perception and adoption of innovation. According to oladosu (2006) farmers in Nigeria usually complained that agricultural extension agents (AEAS) were using unfamiliar terminologies to explain recommended agricultural practices to them and this made them fail to comprehend what was intended by $\left(\mathrm{AEA} \mathrm{A}_{\mathrm{S}}\right)$.

Agricultural development implies a shift from traditional method of production to new, science- based methods of production that include new technological components, such as new verities, cultural practices, commercial fertilizer and pesticides as well as new crops and new farming systems(Madukweet al; 2009). This require effective extension delivering system. This is however lacking particularly in plateau state. This has necessitated putting in place a combination of factors comprising the right technology, effective extension access to physical inputs, adequate market e.t.c to improve agricultural productivity and raise the standard of living of rural dwellers.It is therefore pertinent to ask what the outcomes of extension service delivery in Nigeria particularly plateau state as little or no work has been done in this regard. 


\section{Methodologies}

\subsection{Study Area}

The study was carried out in Jos south local Government area of plateau state. The local government area has a total population of 301,492 people (National population census, 2006), and a total land area of 1,037 square kilometer. The area is located within longitude $80^{\circ} 42^{\prime} \mathrm{N}$ to $80^{\circ} 58^{\prime} \mathrm{N}$ and latitude $90^{\circ} 53 \mathrm{E}$, temperature of $9^{\circ} \mathrm{C}-25^{\circ} \mathrm{C}$ while the mean rainfall varies between $131.75 \mathrm{~cm}$ to $146 \mathrm{~cm}$ (Jos South Local Government Diary, 2006).Under economic activities Jos South Local Government is a hub - nub of industrial activities on the plateau, and some many different varieties of crops are cultivated such as tomatoes, carrots, lettuce, cabbage, green pepper, rice, maize, beans etc. there are satellite vegetable market all over the local government.

\subsection{Population and Sample Size Selection}

The population of the study covers all farmers in selected areas of Jos south local government area of plateau state. The studies utilize a multi - stage random sampling approach to arrive at the sample size. The second stage involved a random selection of two (2) districts which are Kuru and Vwang from the five (5) districts which include Kuru, Vwang, $\mathrm{Du}$, Gyel, Zawan districts in the study area. This is mainly due to their involvement in agricultural activities. The third stage involved a purposive selection of two (2) communities each to arrive at four (4) communities in all. The communities will include Kushe, Dazak, Chugwi and Turu from Kuru and Vwang respectively. Yaro- Yemane formula was used to determine the number of respondents that make up the sample size.

This method will helped in preventing biases and ensured the degree of accuracy that will allow for making inference applicable to a wider population.

\begin{tabular}{|c|c|c|c|c|}
\hline $\begin{array}{l}\text { Selection Local } \\
\text { Government Area }\end{array}$ & $\begin{array}{l}\text { Selected } \\
\text { Districts }\end{array}$ & $\begin{array}{c}\text { Selected } \\
\text { Communities }\end{array}$ & $\begin{array}{l}\text { Sample } \\
\text { Frame }\end{array}$ & $\begin{array}{c}\text { Sample Size } \\
(\mathbf{1 8 . 8 \% )}\end{array}$ \\
\hline Jos south & $\begin{array}{c}\text { Kuru } \\
\text { Vwang }\end{array}$ & $\begin{array}{cc}- & \text { Kushe } \\
- & \text { Dazak } \\
- & \text { Chugwi } \\
- & \text { Turu }\end{array}$ & $\begin{array}{c}183 \\
114 \\
217 \\
69\end{array}$ & $\begin{array}{l}34 \\
21 \\
41 \\
13\end{array}$ \\
\hline Total & & & 583 & 109 \\
\hline
\end{tabular}

Table 1: Sample Size Selection Plan

Source: Field Survey, 2018

Yaro- Yamane formular $=\frac{\mathrm{N}}{1+\mathrm{N}\left(\mathrm{e}^{2}\right)}$

Where $\mathrm{N}=$ Population size

$\mathrm{S}=$ Sample size required

$\mathrm{E}=$ Level of significance

\subsection{Method of Data Collection}

Data was collected using well - structured questionnaire from 109 respondents that will be drawn in the study area. The data collected include; determine the socio-economic characteristics of farmers, identity farmer's perception towards, and ascertain the factors that affect extension service delivery.

\section{Data Analysis}

Objective was analyzed using descriptive statistics such as frequencies, percentages, means and standard deviation. While objective 2 and 3 was analyzed using 3 and 5 points likert scale of, to a very large extent, to a large extent, to some extent, and strongly agreed, agreed, undecided, strongly disagreed and disagreed respectively.

\section{Results and Discussion}

\subsection{Perception of Farmers Regarding Extension Service Delivery}

The result on perception of farmers regarding extension service delivery are presented in table 2 . From the responses gotten, it reveals that average of (4.75) perceived that organization of field meeting with farmers are the best form of extension service delivery, about (4.60) perceived extension service delivery are suitable base on organization of field day with farmers, (4.59) agrees that extension service delivery is suitable by helping to increase their agricultural production, (4.53) through organization of method demonstration, (4.42) through organization of result demonstration, while about (4.33) believe that organization of audio-visual shows are suitable for extension service delivery. The findings shows that most of the farmers has contact with the extension agents on a quarterly basis, which is in line with Aphunu and Otoikhian (2008) that majority of the farmers have contact with extension agents on a monthly basis. According to Aphunu and Otoikhian (2008), there is the need for regular training for extension agents so that reasonable knowledge and experience in adult learning principles could be acquired to enhance their effectiveness. 


\begin{tabular}{|c|c|c|c|c|c|c|c|}
\hline Factors (n = 101) & SA (5) & A (4) & UND (3) & SD (2) & D (1) & Total & Mean \\
\hline Organization of method demonstration & $63(315)$ & $31(124)$ & $5(15)$ & $2(4)$ & $0(0)$ & 458 & 4.53 \\
\hline Organization of result demonstration & $59(295)$ & $31(124)$ & $7(21)$ & $2(4)$ & $2(2)$ & 446 & 4.42 \\
\hline Organization of field meeting with farmers & $80(400)$ & $19(76)$ & $0(0)$ & $2(4)$ & $0(0)$ & 480 & 4.75 \\
\hline Organization of field day with farmers & $69(345)$ & $28(112)$ & $0(0)$ & $4(8)$ & $0(0)$ & 465 & 4.60 \\
\hline Organization of audio- visual shows & $51(255)$ & $38(152)$ & $6(18)$ & $6(12)$ & $0(0)$ & 437 & 4.33 \\
\hline Helping to increase their agriculture production & $62(310)$ & $37(148)$ & $2(6)$ & $0(0)$ & $0(0)$ & 464 & 4.59 \\
\hline
\end{tabular}

Table 2: Linkert Scale Showing the Result on Perception of Farmers Regarding Extension Service Delivery

Note: $\mathrm{SA}=$ Strongly Agree, $\mathrm{A}=$ Agree, $\mathrm{UND}=$ Undecided, $\mathrm{D}=$ Disagree, $\mathrm{SD}=$ Strongly Disagree

(Mean Score > 3.0 = High Determinant Factor)

Source: Field Survey, 2019

\subsection{Factors Affecting Extension Services}

Table 3 shows result rating on the factors affecting extension services among farmers in the study area. The responses reveal that to a very large extent, lack of transport facilities and lack of motivation are the most factors affecting extension services with $80.2 \%$. Others factors identified ranges from lack of trained personal and too many farmers to handle with a percentage rate of $77.2 \%$, time factors and inadequate number of extension agents with percentage rate of $74.3 \%$, low salary (72.3\%), lack of subject matter specialist (59.4\%), lack of teaching aids (58.4\%) and problems of communication/ language barriers with a percentage rate of 53.5\%. This is inline with Agbamu (2005), that Nigeria extension service is devilled by several problems which include inadequacy and instability of funding and poor logistic support for field staff. Omotayo (2004) reported that since the late 1990's, inadequate funding has led to the virtual collapse of research and extension institutions that provided services to small farmers and rural communities in Nigeria.

\begin{tabular}{|c|c|c|c|c|}
\hline Factors & To a Very Large Extent & $\begin{array}{c}\text { To a Large } \\
\text { Extent }\end{array}$ & $\begin{array}{c}\text { To some } \\
\text { Extent }\end{array}$ & Total \\
\hline Lack of trained personal & $78(77.2 \%)$ & $21(20.8 \%)$ & $2(2 \%)$ & $101(100 \%)$ \\
\hline Lack of subject matter specialist & $60(59.4 \%)$ & $39(38.6 \%)$ & $2(2 \%)$ & $101(100 \%)$ \\
\hline $\begin{array}{c}\text { Problems of communication/ language } \\
\text { barriers }\end{array}$ & $54(53.5 \%)$ & $47(46.5 \%)$ & $0(0 \%)$ & $101(100 \%)$ \\
\hline Low salary & $73(72.3 \%)$ & $24(23.8 \%)$ & $4(4 \%)$ & $101(100 \%)$ \\
\hline Lack of transport facilities & $81(80.2 \%)$ & $12(11.9 \%)$ & $8(7.9 \%)$ & $101(100 \%)$ \\
\hline Time factors & $75(74.3 \%)$ & $22(21.8 \%)$ & $4(4 \%)$ & $101(100 \%)$ \\
\hline Lack of teaching aids & $59(58.4 \%)$ & $38(37.6 \%)$ & $4(4 \%)$ & $101(100 \%)$ \\
\hline Inadequate number of extension agents & $75(74.3 \%)$ & $22(21.8 \%)$ & $4(4 \%)$ & $101(100 \%)$ \\
\hline Too many farmer to handle & $78(77.2 \%)$ & $23(22.8 \%)$ & $0(0 \%)$ & $101(100 \%)$ \\
\hline Lack of motivation & $81(80.2 \%)$ & $20(19.8 \%)$ & $0(0 \%)$ & $101(100 \%)$ \\
\hline
\end{tabular}

Table 3: Factors Affecting Extension Services

Source: Field Survey, 2019

\section{Conclusion and Recommendations}

\subsection{Conclusion}

The study revealed that majority of the farmers are in their active years and are aware of the usefulness of extension service which bring about increase in their productivity. The extensive methods are perceived to be effective by famers in the study area and have impact. Regular farm visit is important or vital for dissimilation of extension messages and should be encouraged at all times to bring about the needed change in the area. The study revealed that male dominate the agricultural sectors in the study area. Also to a very large extent, lack of transport facilities and lack of motivation are the most factors affecting extension services in the study area.

\subsection{Recommendation}

Government should create a sensitization programmes to provide good working condition and enlightenment to the farmers and to lectures them on the need of extension agent would bring change in the region and farmers should seek contact advice from extension agents on knowledge and skill to increase their yields. The state government should enforce easy accessibility of agricultural extension agents to the farmers. This is because the more the frequency of contact of farmers with extension agents, the better the effectiveness of the extension service. Proper planning of programme and effective dissemination of information to the rural farmers should be made by the extension agents to facilitate timely dissemination of information, so as to enhance productivity. 


\section{References}

i. Aderity, F.O and Ajiya, A.O (2011).Concepts and basic principles of agricultural Extension in Nigeria - publication of Agricultural Extension Society of Nigeria (AESON).

ii. Agbanu, J.U. (2005). Problem and prospects of agricultural extension services in development countries in Agricultural Extension. In: Nigeria S.F. Afolayan (Ed) Ilorin Atson, p. 159-169.

iii. Aphunu, A. and Otoikhian, C.S.O (2008). Farmers perception of the effectiveness of extension agents of Delta state Agricultural Development Programme (DADP) Ayr.J. Gen. Agric. 4 (3): 165-169.

iv. Ayansina, S.O (2011); farmer perception of public and extension services in South western Nigeria being a P.h.D unpublished thesis submitted to department of Agricultural extension and rural development, University of llorin.

v. Ayayi, A.R (2009) the role expectation of agriculture extension in poverty alleviation in a democratic and deragulated economy. A paper presented at the $9^{\text {th }}$ annual conference.

vi. Babasanya, B, Oladele, O.G and Odide, O.O (2013). Farmer's perception and knowledge need for adoption of new cassava cultivars inn Igabi L.G.A of Kaduna State. Journal of biology, Agriculture and health care 3(2) 45-52

vii. Jos South L.G.A Diary(2009).

viii. Madukwe, M.C. and Erie (2009). "An analysis of the agricultural Knowledge system for transfer of science and technology to farmers in Nigeria", The Nigeria Rural Sociologist, Vol. 3,pp. 1-6.

ix. National population census 2006.

x. Madukwe, M.C. and Erie (2009). "An analysis of the agricultural Knowledge system for transfer of science and technology to farmers in Nigeria", The Nigeria Rural Sociologist, Vol. 3, pp. 1-6.

xi. Ogunremi, J.B., Faturoti, E.O. and Oladele, O.I. (2013). The influence of extension agents personal characteristics on technology linkage in Oyo State, Nigeria. Biological and Environmental Science Journal for the Tropics 9(2): 124-128.

xii. Oladosu I.O (2006); implications of farmers attitude towards Extension agents in future extension programme planning in Oyo State of Nigeria.J. Soc. Sci; 12.

xiii. Omotayo, A., Chikwendu, O.D. And Adebayo K. (2006). Two decades of World Bank assisted extension services in Nigeria: Lessons and challenges for the future. Journal of Agriculture Education and Extension, 7(3): 143 - 152.

xiv. Rivera. W; Zijp, W and Gary, A. (2012). Contracting for extension: review of emerging practices. Akis good practice notes, thematic group. Washington. D.C World Bank. 